\title{
ТРАНСЦЕНДЕНТАЛЬНЫЙ СОЛИПСИЗМ
}

\section{ЯРОСЛАВ СЛИНИН}

Доктор философских наук, профессор.

Санкт-Петербургский государственный университет, Институт философии.

199034 Санкт-Петербург, Россия.

E-mail: slinin@mail.ru

В статье я намерен показать, что декартово правило не принимать за истинное ничего неочевидного и сомнительного приводит к солипсизму. Следуя этому правилу, Декарт получил изначальную абсолютную истину: «Я мыслю, следовательно, я существую». Однако из моего несомненного существования такое существование для других «я» не следует. Декарт попытался выйти из положения, сформулировав онтологическое доказательство бытия Божьего. Это доказательство не может быть признано состоятельным, поскольку далеко не все его шаги столь же несомненны, сколь истина cogito ergo sum. Таким образом, угроза солипсизма Декартом не была устранена. В дальнейшем Э. Гуссерль, желая преодолеть релятивизм и скептицизм, будучи убеждён в том, что всё истинное истинно абсолютно, и полагая, что всякая абсолютная истина должна быть несомненной, предпринял попытку обнаружить такие истины. Его процедура феноменологической редукции явилась усовершенствованным вариантом картезианского сомнения. Она привела к тому результату, что несомненным является только существование трансцендентального «я» и всего того, что ему имманентно. Этот результат соответствует картезианскому положению о несомненности sum cogitans. Согласно Гуссерлю, в области сомнительного трансцендентного оказалось автономное существование Бога и природы. Что касается существования других «я», то оно, по Гуссерлю, трансцендентно и в то же время несомненно: об этом свидетельствует находящаяся в распоряжении sum cogitans аппрезентация, представляющая собой аналогическую апперцепцию. Однако, с моей точки зрения, аналогическая апперцепция имеет ничуть не большую доказательную силу, чем онтологическое доказательство Декарта. Она не может обосновать положение о том, что трансцендентное существование других «я» очевидно и несомненно. Таким образом, своего рода трансцендентный солипсизм оказывается непреодолённым. В конце статьи я анализирую две основные характеристики sum cogitans: его контингентность и его прерывистость. Ключевые слова: Скептицизм, Декарт, методическое сомнение, Гуссерль, феноменологическая редукция, аналогическая апперцепция.

(C) YAROSLAV SLININ, 2017 


\section{TRANSCENDENTAL SOLIPSISM}

\section{YAROSLAV SLININ}

DSc in Philosophy, Professor.

St. Petersburg State University, Institute of Philosophy.

199034 Saint-Petersburg, Russia.

E-mail: slinin@mail.ru

In the article I intend to demonstrate that the Cartesian rule never to accept anything unobvious and doubtful for true ends up with solipsism. Confines himself to this rule Descartes obtains an elemental and absolute truth of "I think, therefore I am". However, the doubtless existence of my ego does not imply the doubtless existence of the other egos. Descartes tried to find a way out by composing the ontological argument for the existence of God. This argument cannot be recognized as sound since by no means all of it transitions are doubtless just as cogito ergo sum is. As a result Descartes failed to eliminate the solipsism problem. At a later stage Husserl trying to overcome relativism and skepticism, being convinced that each truth is an absolute and believing that all absolute truth must be doubtless attempted to discover such truth. Husserl's procedure of the phenomenological reduction appeared to be an improved version of Descartes's method of doubts. It delivers the result that the only existence of transcendental ego and everything that is immanent to it is doubtless. This result corresponds to the Cartesian thesis of the obviousness of sum cogitans. According to Husserl the autonomous existence of God and nature turn out to belong to the domain of doubtful transparentness. As for the existence of other egos, according to Husserl it is transcendental and doubtless at the same time. The sum cogitans appresentation which is an analogical apperception bears witness for that fact. From my point of view, nevertheless, an argumentativeness of the analogical apperception is no better than that of Descartes ontological argument. It cannot provide rationalization for the thesis that the transcendental existence of other egos is obvious and doubtless. Thus, the transcendental solipsism stays ambiguous. In the end of the article I am analyzing the two main characteristics of sum cogitans: its contingency and discreteness.

Key words: Skepticism, Descartes, methodological doubt, Husserl, phenomenological reduction, analogous apperception.

1.

В трактате Секста Эмпирика «Три книги Пирроновых положений» говорится, что одно из основополагающих утверждений античного скептицизма таково: «Всякому рассуждению противостоит равное» (Sekst Empirik, 1976, 248). Исходя из него «скептик не выставляет никаких догм» (Sekst Empirik, 1976, 209). В самом деле: «Выставляющий догму полагает, что та вещь, которая считается предметом его догматизирования, действительно существует, скептик же не уверен, что известное положение непременно существует» (Sekst Empirik, 1976, 210). В результате, применительно к любому догматически выставляемому положению скептик прибегает к غ̇лохи́ - «воздержанию от суждения». 
Секст Эмпирик поясняет: “Воздержание от суждения” есть такое состояние ума, при котором мы ничего не отрицаем и ничего не утверждаем» (Sekst Empirik, 1976, 209).

Таким образом, согласно античным скептикам, ничего нельзя ни утверждать, ни отрицать категорически; допустимы одни лишь проблематические (гипотетические) высказывания. Это означает, что в соответствии с их учением, относительно чего бы то ни было не существует никакого несомненного

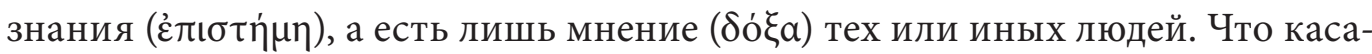
ется мнений, то о них у Секста Эмпирика сказано следующее:

В самом деле, мы будем доверять либо всем людям, либо некоторым: если всем,
то мы будем как браться за невозможное, так и принимать противополож-
ности; если же некоторым, то пусть нам скажут, с кем нам надо соглашаться.
Платоник будет говорить, что с Платоном, эпикуреец - с Эпикуром, и соответ-
ственно все прочие. И таким образом, враждуя между собой без определенного
решения, они снова приведут нас к воздержанию от суждения. (Sekst Empirik,
1976, 225)

Не следует думать, будто утверждения скептиков имеют чисто декларативный характер и недостаточно обоснованы. Нет, представители античного скептицизма были весьма въедливыми и отнюдь не ленивыми исследователями. Они тщательно изучили все существовавшие в их время науки и философские направления. Они сумели началам всех наук и основоположениям всех философских школ противопоставить равное. И поскольку эти начала и эти основоположения оказались под вопросом, постольку и все вытекающие из них рассуждения также попали под вопрос. В том, что такая «разрушительная» работа была скептиками проделана мастерски, можно убедиться, ознакомившись с обширным трактатом Секста Эмпирика «Против ученых», содержащим разделы: Против грамматиков, Против риторов, Против геометров, Против арифметиков, Против астрологов, Против музыкантов, Против логиков, Против физиков и Против этиков.

Из своего скрупулезно проведенного исследования античные скептики делают следующий вывод, касающийся житейской практики: так как невозможно отличить то, что по своей природе истинно, от того, что ложно, а то, что по своей природе хорошо, от того, что дурно, значит, следует воздержаться от изысканий и жить невозмутимо в соответствии с обычаями того обще-

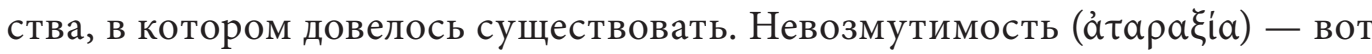
цель античного скепсиса. 
Прошло около двух тысячелетий, и проблемы, волновавшие античных скептиков, стали актуальными для великого французского философа и ученого Рене Декарта. В своем знаменитом сочинении «Рассуждение о методе, чтобы верно направлять свой разум и отыскивать истину в науках» он пишет о себе так:

А между тем я учился в одной из самых известных школ в Европе и полагал, что если есть на земле где-нибудь ученые люди, то именно там они и должны быть. Я изучал там все, что изучали другие, и, не довольствуясь сообщаемыми сведениями, пробегал все попадавшиеся мне под руку книги, где трактуется о наиболее редкостных и любопытнейших науках. (Dekart, 1989a, 252)

Среди всего того, что внимательно изучил Декарт, было и учение античных скептиков. Он принял вторую часть их житейской максимы, которую мы привели выше, но отверг первую ее часть. По совету скептиков, Декарт в своей жизни решил следовать правилу «повиноваться законам и обычаям моей страны, неотступно придерживаясь религии, в которой, по милости божией, я был воспитан с детства, и руководствуясь во всем остальном наиболее умеренными чуждыми крайностей мнениями, сообща выработанными самыми благоразумными людьми, в кругу которых мне предстояло жить» (Dekart, 1989a, 263). Однако рекомендацию воздержаться от изысканий французский мыслитель не принял. Он решил продолжить изыскания скептиков и, прежде всего, проверить, к правильным ли заключениям эти изыскания их привели.

В трактате «Три книги Пирроновых положений» сказано: «Пирроник же не признает ничего неочевидного» (Sekst Empirik, 1976, 210). Декарт сделал этот афоризм скептиков отправной точкой своих рассуждений, преобразовав его в ставшее знаменитым правило:

Первое - никогда не принимать за истинное ничего, что я не признал бы таковым с очевидностью, т. е. тщательно избегать поспешности и предубеждения и включать в свои суждения только то, что представляется моему уму столь ясно и отчетливо, что никоим образом не сможет дать повод к сомнению. (Dekart, 1989a, 260)

Так это правило сформулировано в уже упоминавшемся нами трактате «Рассуждение о методе». В том же трактате Декарт следующим образом воспользовался им: 
С давних пор я заметил, что в вопросах нравственности иногда необходимо мнениям заведомо сомнительным следовать так, как если бы они были бесспорны. [...] Но так как в это время я желал заняться исключительно разысканием истины, то считал, что должен поступить совсем наоборот, т. е. отбросить как безусловно ложное все, в чем мог вообразить малейший повод к сомнению, и посмотреть, не останется ли после этого в моих воззрениях чего-либо уже вполне несомненного. (Dekart, 1989a, 268)

Скептики утверждают, что ничего несомненного не существует. Видим, что Декарт решил проверить, так ли это: не найдется ли все-таки чего-либо вполне несомненного, античными скептиками не замеченного?

Вот как французский мыслитель организовал такую проверку:

Таким образом, поскольку чувства нас иногда обманывают, я счел нужным допустить, что нет ни одной вещи, которая была бы такова, какой она нам представляется; и поскольку есть люди, которые ошибаются даже в простейших вопросах геометрии и допускают в них паралогизмы, то я, считая и себя способным ошибаться не менее других, отбросил как ложные все доводы, которые прежде принимал за доказательства. Наконец, принимая во внимание, что любое представление, которое мы имеем в бодрствующем состоянии, может явиться нам и во сне, не будучи действительностью, я решился представить себе, что все когда-либо приходившее мне на ум не более истинно, чем видения моих снов. (Dekart, 1989a, 268)

Данное рассуждение представляет собой конспект того, о чем гораздо более пространно уже говорили античные скептики. Секст Эмпирик в трактате «Три книги Пирроновых положений» приводит десять тропов древних и пять тропов младших скептиков, предназначенных для доказательства ненадежности как чувственного восприятия, так и ума, а также невозможности отличить видимое во сне от видимого наяву. И на этом изыскания как древних, так и младших скептиков заканчиваются с тем результатом, что все иллюзорно, что ничего нельзя ни доказать, ни опровергнуть, а то «что мы видим во сне [...] существует во сне точно так же, как существует явь» (Sekst Empirik, 1976, 228).

Что касается Декарта, то его изыскания на этом не заканчиваются. Он пишет:

Но я тотчас обратил внимание на то, что в это самое время, когда я склонялся к мысли об иллюзорности всего на свете, было необходимо, чтобы я сам, таким образом рассуждающий, действительно существовал. И заметив, что истина Я мыслю, следовательно, я существую столь тверда и верна, что самые сумасбродные предположения скептиков не могут ее поколебать, я заключил, что могу без опасений принять ее за первый принцип искомой мною философии. (Dekart, 1989a, 268-269) 
Перед нами великое открытие Декарта. Он установил, что заключение скептиков, гласящее, что «Все высказывания проблематичны», оказалось преждевременным. Ему удалось найти истинное высказывание, имеющее категорический характер: положение «Я мыслю, следовательно, я действительно существую» несомненно, ему нельзя противопоставить равное. Декартово cogito ergo sum неопровержимо.

3.

Но что представляю собой я, в действительном существовании коего невозможно усомниться?

Декарт разъясняет:

Затем, внимательно исследуя, что такое я сам, я мог вообразить себе, что у меня нет тела, что нет ни мира, ни места, где я находился бы, но я никак не мог представить себе, что вследствие этого я не существую; напротив, из того, что я сомневался в истине других предметов, ясно и несомненно следовало, что я существую. А если бы я перестал мыслить, то, хотя бы все остальное, что я когда-либо себе представлял, и было истинным, все же не было основания для заключения о том, что я существую. Из этого я узнал, что я - субстанция, вся сущность, или природа, которой состоит в мышлении и которая для своего бытия не нуждается ни в каком месте и не зависит ни от какой материальной вещи. Таким образом, мое я, душа, которая делает меня тем, что я есмь, совершенно отлична от тела и ее легче познать, чем тело; и если бы его даже вовсе не было, она не перестала бы быть тем, что она есть. (Dekart, 1989a, 269)

Разъяснение Декарта имеет кардинальный характер. Из него вытекает, что несомненно я существую лишь в качестве собственного мышления. Действительность существования моего тела остается под вопросом. Под вопросом остается действительное существование всего пространственного мира.

Заметим, что термин «мышление» Декарт употребляет в самом широком смысле. Этим словом он обозначает то, что мы теперь обычно называем сознанием. В трактате «Размышления о первой философии» он пишет: «Итак, что же я есмь? Мыслящая вещь. А что это такое - вещь мыслящая? Это нечто сомневающееся, понимающее, утверждающее, отрицающее, желающее, не желающее, а также обладающее воображением и чувствами» (Dekart, 1994, 24). Таким образом, согласно Декарту, категорически я могу утверждать лишь то, что существую сам в качестве собственного сознания. Что же касается моего тела и всего пространственного мира, в котором оно находится, то 
они имеют, в лучшем случае, только гипотетическое существование. Но что если cogito ergo sum - это единственная несомненная истина, и других больше нет? В этом случае возникает угроза солипсизма. Ведь из того, что я мыслю, следует только то, что я существую, а не то, что существуют также и другие. Существование других сознаний не в меньшей степени проблематично, чем существование телесного мира.

Декарт нигде прямо и открыто не ставил вопроса о солипсизме, но оставаться наедине со своим cogito ergo sum не собирался. Французский философ предпринял попытку найти еще какие-нибудь истины, в которых нельзя было бы усомниться, и которые были бы столь же тверды и верны, как первоначальная. В качестве второй по счету несомненной истины Декарт предложил утверждение: «Я мыслю, следовательно, Бог действительно существует».

Утверждение «Бог действительно существует», взятое само по себе, не является очевидным и несомненным. Ему можно противопоставить равное. Высказыванию «Бог есть» всегда можно противопоставить высказывание «Бога нет». Еще в седой древности находились люди, которые так поступали. Достаточно вспомнить место из «Псалтыри», которое пытался нейтрализовать Ансельм Кентерберийский: «Сказал безумец в сердце своем: “нет Бога”» (Пс 13, 1; 52, 2).

Декарт, разумеется, был согласен с тем, что действительное существование Бога сомнительно. В его сочинении «Первоначала философии» написано:

\footnotetext{
Итак, отбросив все то, относительно чего мы можем каким-то образом сомневаться, и, более того, воображая все эти вещи ложными, мы с легкостью предполагаем, что никакого Бога нет, и нет ни неба, ни каких-либо тел, что сами мы не имеем ни рук, ни ног, ни какого бы то ни было тела; однако не может быть, чтобы в силу всего этого мы, думающие таким образом, были ничем: ведь полагать, что мыслящая вещь в то самое время, как она мыслит, не существует, будет явным противоречием. А посему положение Я мыслю, следовательно, я существую - первичное и достовернейшее из всех, какие могут представиться кому-либо в ходе философствования. (Dekart, 19896, 316)
}

Итак, я не только могу «вообразить себе, что у меня нет тела, что нет ни мира, ни места, где я находился бы», но и «с легкостью» предположить, что «никакого Бога нет».

При всем том Декарт не был намерен ставить Бога в один ряд с небом, землей и разного рода находящимися в пространстве телами. Он посчитал, что, исходя из несомненности sum cogitans, сможет при помощи рассуждения, каждый шаг которого несомненен, доказать несомненность действительности 
существования Бога и опровергнуть тем самым сделанное слишком поспешно предположение о том, что Его нет.

Рассуждение Декарта сводится к следующему. Обследовав состав своего сознания, он обнаружил в нем «способность мыслить о чем-нибудь более совершенном, чем я сам, и понял со всей очевидностью, что это должно прийти от чего-либо по природе действительно более совершенного» (Dekart, 1989a, 269). Так он пришел «к идее существа более совершенного, чем я» (Dekart, 1989a, 270) и продолжил свое рассуждение следующим образом:

Поскольку неприемлемо допускать, чтобы более совершенное было следствием менее совершенного, как и предполагать возникновение какой-либо вещи из ничего, то я не мог сам ее создать. Таким образом, оставалось допустить, что эта идея была вложена в меня тем, чья природа совершеннее моей и кто соединяет в себе все совершенства, доступные моему воображению, - одним словом. Богом. (Dekart, 1989a, 270)

Если рассуждение Декарта безупречно, и несомненность действительного существования Бога доказана, то не подлежит сомнению и дальнейшее: поскольку в число совершенств Бога входит всеблагость, постольку Он не станет обманывать меня и показывать мне вместо того, что́ сотворил, нечто другое. Поэтому если Бог существует несомненно, то столь же несомненно существует и созданный Им мир. Вот к какому итогу, к какого рода философии стремился Декарт. Отметим, что если все сказанное французским философом принимается, то тем самым устраняется и угроза солипсизма (может быть, поэтому он ее и не замечал): другие, входя в состав действительного мира, существуют вместе с ним столь же несомненно, сколь и я сам.

Впрочем, как-то даже не верится, что Декарт мог всерьез считать все шаги своего рассуждения такими же несомненными, какова первоначальная истина cogito ergo sum. Ведь невооруженным глазом видно, что рассуждение это относится к числу тех, которым, по словам античных скептиков, противостоит равное. В первую очередь, никак нельзя признать несомненным тезис: «неприемлемо допускать, чтобы более совершенное было следствием менее совершенного». Ему вполне можно противопоставить положение «более совершенное является следствием менее совершенного», что, например, и утверждается современными эволюционистами в отношении генезиса органической природы. Учение Дарвина многими оспаривается, но в равной степени спорным является и противостоящий ему тезис Декарта. Значит, положение о том, что я самостоятельно не могу помыслить о чем-то более совершенном, чем 
я сам, тем более не является несомненным. И уж совсем неочевидным является положение о том, будто внутрь моего сознания можно вообще «вложить» что-либо извне.

Таким образом, онтологическое доказательство бытия Божьего, предложенное Декартом, приходится признать несостоятельным, а все, что из него вытекает, - сомнительным. Несомненной остается лишь первоначальная декартова истина: «Я мыслю, следовательно, я существую». И это означает, что таящаяся в ней угроза солипсизма остается в силе.

4.

Так что Декарт, как говорится, начал «за здравие», а кончил «за упокой». Опираясь на свое правило «никогда не принимать за истинное ничего, что я не признал бы таковым с очевидностью», он смог опровергнуть тезис античных скептиков: «Всякому рассуждению противостоит равное», обнаружив истину cogito ergo sum, которая «столь тверда и верна, что самые сумасбродные предположения скептиков не могут ее поколебать». Но, к сожалению, она оказалась единственной несомненной истиной. Для того чтобы развернуть искомую им новую философию, Декарту пришлось вольно или не вольно отказаться от вышеупомянутого правила: все остальные положения и рассуждения французского мыслителя, начиная с его онтологического доказательства, таковы, что любому из них скептики смогли бы противопоставить равное. Его новая философия с ee res extensa и res cogitans оказалась обычным догматическим учением, таким же, каковы, например, учения Демокрита, Платона, Аристотеля или средневековых богословов.

Что касается философов, творивших после Декарта, то его онтологического доказательства никто из них не принял. Против истины cogito ergo sum возражений, естественно, не было, но она слыла не новой, банальной и маловажной. Некоторые из последекартовских философов шли на поводу у скептиков, признавая собственные концепции чисто релятивистскими, то есть состоящими лишь из относительных истин, из гипотез и допущений. Другие декларативно объявляли положения своих концепций абсолютно истинными и бесспорными подобно тому, как это делали античные догматики и средневековые схоласты. Так продолжалось вплоть до того, как уже в наше время Эдмунд Гуссерль со всей серьезностью обратился к борьбе с релятивизмом и к декартовскому способу опровержения скептицизма. 
Для формирования гуссерлевой феноменологии наибольшее значение имели учение Лейбница о «монадах без окон», трансцендентализм Канта и учение Франца Брентано об интенциональном характере актов сознания.

Особенно важным является трансцендентальное истолкование Кантом пространства и времени, его учение о том, что они отнюдь не трансцендентны сознанию, а суть лишь имманентные условия чувственности. Кант, таким образом, свел декартовы res extensa к частному случаю res cogitans. Правда, при этом кенигсбергский философ чисто догматически утверждал, что трансцендентные сознанию вещи в себе существуют, будучи абсолютно непознаваемыми, но каким-то неведомым образом все же аффицирующими его. Ясно, что наличие таких вещей в себе легко оспорить, что, как известно, и было сделано сначала Фихте, а затем и другими философами-трансценденталистами.

Гуссерль тоже ставил под сомнение действительность существования трансцендентных сознанию вещей в себе. При построении своей философии он отталкивался от дескриптивной психологии Франца Брентано, в основе которой лежит положение о том, что всякий акт сознания интенционален. Согласно как Брентано, так и Гуссерлю, в потоке внутреннего времени сознания один акт следует за другим, причем каждый из них представляет собой интенцию, то есть направленность на что-то, на какой-то объект, на какой-то свой предмет.

Акты сознания разнообразны; их разновидности перечислил еще Декарт в определении sum cogitans, которое было приведено выше. Он определял sum cogitans как «нечто сомневающееся, понимающее, утверждающее, отрицающее, желающее, не желающее, а также обладающее воображением и чувствами». Брентано и Гуссерль подчеркивают, что всякий акт моего сомнения направлен на что-то, в чем я сомневаюсь, а всякий акт моего понимания нацелен на нечто, понимаемое мною. Точно так же и мои акты утверждения и отрицания, желания и нежелания направлены на что-то, мною утверждаемое или отрицаемое, равно как и на что-то, мною желаемое или не желаемое соответственно. Акты моего воображения нацелены на какие-то воображаемые мною предметы, а акты моего чувственного восприятия - на те или иные воспринимаемые мною здесь и теперь индивидуальные объекты.

Те предметы, те объекты, на которые направлены все эти многообразные акты сознания, Гуссерль называет интенциональными объектами. Но каков онтологический статус интенциональных объектов? Ясно, что они имманентны сознанию, представляют собой некий «слой» сознания. В своей книге 
«Идеи к чистой феноменологии и феноменологической философии» Гуссерль называет сам акт сознания, саму интенцию, ноэзой, а объект, на который она направлена - ноэмой. В трактате «Картезианские размышления» акт сознания именуется когитацией, а то, на что он нацелен - когитатумом. Позаимствовав терминологию у Канта и Гегеля, Гуссерль характеризует слой интенциональных объектов как мир феноменов.

В те времена, когда Гуссерль начинал свою творческую деятельность, в западноевропейской философии господствовал так называемый «психологизм». Молодой философ вступил в борьбу с психологизмом из-за того, что последнему был присущ релятивизм. «Психологизм как скептический релятивизм» - такой заголовок дал Гуссерль одной из глав первого тома своих «Логических исследований» (Gusserl', 1909, 95).

Релятивизм утверждает, что абсолютных истин нет, а существуют лишь относительные истины, каждая из которых противостоит другим, ей равноправным и равноценным. Так, например, истина Платона несовместима с истиной Эпикура, и обе они противостоят истине Аристотеля. При этом каждая из них не лучше и не хуже двух других, равно как не лучше и не хуже истин всех других мыслителей, когда-либо существовавших на земле. Ясно, что релятивизм - это одна из разновидностей скептицизма: каждый мыслитель, не соглашаясь с истинами других, противопоставляет им равное в виде собственной истины. Релятивизмом заражен и так называемый «историзм», который Гуссерль подверг критике в программном очерке «Философия как строгая наука» и который утверждает, что всякому историческому периоду присущи свои истины, отличные от равноценных им истин, свойственных другим историческим периодам.

Гуссерль решительно воспротивился релятивизму во всех его формах. Он высказался в пользу того, что абсолютные истины все-таки существуют; нужно их только найти. Ему принадлежит следующая «крылатая» фраза: «Что истинно, то абсолютно, истинно “само по себе"; истина тождественно едина, воспринимают ли ее в суждениях люди или чудовища, ангелы или боги» (Gusserl', 1909, 101).

И Гуссерль приступил к поискам абсолютно истинного. Сначала он решил, что абсолютными являются лейбницевские истины разума: «Об этой истине говорят логические законы, и мы все, поскольку мы не ослеплены релятивизмом, говорим об истине в смысле идеального единства в противовес реальному многообразию рас, индивидов и переживаний» (Gusserl', 
1909, 101-102). Однако постепенно он пришел к выводу, что абсолютной имеет право называться лишь такая истина, которая никогда не вызывает никакого сомнения, а лейбницевские истины разума, к сожалению, этому требованию не удовлетворяют.

Для того чтобы обнаружить несомненное, Гуссерль в «Идеях к чистой феноменологии и феноменологической философии» предложил процедуру «феноменологической редукции». Эта процедура представляет собой модификацию декартова метода сомнения: «Картезиев опыт универсального сомнения мы могли бы заместить теперь универсальной є́лохй в нашем строго определенном и новом смысле» (Gusserl', 2009, 100).

Свою феноменологическую редукцию Гуссерль называет также «методом введения в скобки»: в скобки вводится все то, действительное существование чего сомнительно. Все попавшее в скобки, все, существование чего не является несомненным, следует «выключить из рассмотрения».

Вот каковы «шаги» гуссерлевой редукции: «выключение трансцендентности бога», «выключение чистой логики как mathesis universalis», «выключение материально-эйдетических дисциплин» (Gusserl', 2009, 179-183). Видим, что они mutatis mutandis соответствуют «шагам» методического сомнения Декарта. И результат феноменологической редукции подобен результату методического сомнения: в скобки никак нельзя заключить чистое Я, ввиду очевидности его действительного существования. «Чистое», или «трансцендентальное», сознание представляет собой «феноменологический остаток» (Gusserl', 2009, 102).

В разбираемой нами книге Гуссерля есть параграф, озаглавленный: «Несомненность имманентного - сомнительность трансцендентного восприятия». В нем можно прочесть следующее:

Так что теперь во всех отношениях становится ясно, что все, что есть для меня здесь в вещном мире, - это принципиально только прозумптивная действительность, что напротив того я сам, для кого она есть здесь (за вычетом того, что «мною» будет приписано к вещному миру), или же, иначе, актуальность моих переживаний есть абсолютная действительность, данная через безусловное и абсолютно неустранимое полагание. (Gusserl', 2009, 141)

И далее:

Итак, тезису мира - мир «случаен» - противостоит тезис моего чистого Я, жизни моего Я, которая является «необходимой», абсолютно несомненной. Все вещное с его живой телесной данностью может и не быть, но не может быть такого переживания, даваемого с живой телесностью, какого могло бы и не 
бъımb, - это сущностный закон, какой определяет и эту необходимость, и эту случайность. (Gusserl', 2009, 141)

Здесь написано примерно то, с чем мы уже познакомились, читая «Рассуждение о методе» Декарта. Однако разница между подходом Декарта и подходом Гуссерля, конечно, есть, и немалая.

Во-первых, Декарт лишь констатирует, что «истина Я мыслю, следовательно, я существую столь тверда и верна, что самые сумасбродные предположения скептиков не могут ее поколебать». А Гуссерль, приняв во внимание то, что всякий акт мышления интенционален, установил следующее: сомнению не подлежит действительное существование не только самого акта мышления, но и того, на что он направлен, того, о чем я в это время мыслю. Если несомненно существует мое cogito, то столь же несомненно существует его cogitatum. Если я несомненно существую как Я мыслящее, то столь же несомненно существует и мыслимое мною, но, разумеется, исключительно как мыслимое, всего лишь как интенциональный объект.

Декарт не раскрыл содержания своей твердой и верной истины, а Гуссерль сделал это. Оказалось, что не подлежащим сомнению является не только скромное sum cogitans, но и весь мир феноменов, весь этот богатейший слой моих интенциональных объектов. Ведь все феномены, согласно Гуссерлю, имманентны моему сознанию, а все имманентное несомненно. Зато все трансцендентное сомнительно. Допустим, что я смотрю на этот стол, понимаю, что это - стол, и оцениваю его как хороший стол. Действительность существования этого стола независимо от моего сознания сомнительна: мы помним, что все трансцендентное находится внутри скобок. Трансцендентное существование этого стола может быть только проблематическим, гипотетическим. Но его существование как феномена, как интенционального объекта, имманентного моему сознанию, отнюдь не гипотетично: оно сомнению не подлежит.

Во-вторых, Гуссерль, поместив «трансценденцию Бога» в скобки, так и оставил ее там. Декарт, как мы помним, признав вначале, что в реальном существовании Бога вполне можно усомниться, затем попытался уничтожить такую возможность при помощи онтологического доказательства. Гуссерль же ничего подобного не сделал: для него трансцендентное существование Бога имеет лишь гипотетический статус существования.

В результате, Гуссерль остался наедине с собственным сознанием и миром феноменов, имманентных последнему. Лишь существование чистого 
трансцендентального Я оказалось несомненным. И тут, когда Бог уже никак не мог помочь, угроза солипсизма стала явной и ничем не прикрытой. Гуссерлевская феноменология столкнулась с ней лицом к лицу. Повторим: из cogito ergo sum, из того, что мое чистое трансцендентальное Я существует со всей несомненностью, отнюдь не вытекает, что с той же несомненностью существуют и другие чистые трансцендентальные Я, трансцендентные моему $Я$.

В «Идеях к чистой феноменологии и феноменологической философии» Гуссерль еще ничего не пишет о солипсизме, но к моменту написания «Картезианских размышлений» он его угрозу полностью осознал, но не захотел признать, что его феноменология ведет к солипсизму. Он попытался вышеназванную угрозу нейтрализовать.

5.

Вот что можно прочесть в «Картезианских размышлениях» Гуссерля:

Если я, как размышляющее Я, редуцирую себя посредством феноменологического в́лохи́ к своему абсолютному трансцендентальному ego, то не становлюсь ли я после этого неким solus ipse и не остаюсь ли таковым до тех пор, пока под знаком феноменологии занимаюсь последовательным самоистолкованием? И не следует ли в таком случае объявить феноменологию, вознамерившуюся решить проблемы объективного бытия и выступать уже в качестве философии, трансцендентальным солипсизмом? (Gusserl', 1998, 182)

Видим, что Гуссерль очень четко формулирует угрозу, нависшую над его учением: оно рискует стать трансцендентальным солипсизмом. Однако он уверен, что подобная угроза не страшна его философии. По его мнению, трансцендентальная феноменология вовсе не является трансцендентальным солипсизмом. В «Картезианских размышлениях» Гуссерль попытался этот тезис доказать.

Он рассуждал следующим образом. Все многообразие когитатумов моих когитаций делится на две части. Одна из них - это сфера «моего», моей «самости»; другая часть - это область «не моего», область «чужого». В сферу «моего» входит феномен принадлежащего мне одушевленного тела, феномен моего «живого тела», если воспользоваться терминологией Гуссерля, который, впрочем, термин «живое тело» нередко заменяет выражением «психофизическая структура». Область «не моего» составляют феномены всех тех вещей, которые к моей психофизической структуре не относятся. Но вот что важно: 
наблюдая эту область, я замечаю наличие в ней множество феноменов других, не моих, психофизических структур, аналогичных моей. А теперь самое главное: согласно Гуссерлю, при виде других, не моих, психофизических структур мне становится ясно, что «за каждой из них стоит» другое, не мое, трансцендентальное еgo, подобное моему, не входящее в число моих феноменов и, стало быть, трансцендентное моему чистому Я.

Видим, что в «Картезианских размышлениях» Гуссерль отступил от выдвинутого им в «Идеях к чистой феноменологии и феноменологической философии» положения: «Несомненность имманентного - сомнительность трансцендентного восприятия». Теперь он утверждает, что нечто трансцендентное может-таки быть воспринято без сомнения в действительности его существования.

Гуссерль обнаружил, что в моем сознании наличествует некая особого рода «аппрезентация», представляющая собой «аналогическую апперцепцию». Он пишет: «Речь, следовательно, идет о своего рода приведении-в-со-приcymcmвие, о некой аппрезентации» (Gusserl', 1998, 214). Эта аппрезентация имеет аналогический характер, характер особого рода уподобления. Причем Гуссерль предупреждает: «Таким образом, мы имели бы дело с некого рода уподобляющей апперцепцией, но ни в коем случае не с выводом по аналогии. Апперцепция не есть вывод, не есть рассудочный акт» (Gusserl', 1998, 217).

Аналогическая апперцепция есть прямая непосредственная интенция, своего рода интуиция. Она позволяет при созерцании других психофизических структур осуществить «схватывание» того, что за каждой из них скрывается другое трансцендентальное ego, трансцендентальное по отношению к моему. Как пишет Гуссерль:

\begin{abstract}
Аппрезентация, в которой дан недоступный originaliter компонент «другого», сопряжена с некой изначальной презентацией (презентацией его тела как части природы, данной в моей собственной сфере). Но в этом сопряжении живое тело «другого» и управляющее этим телом «другое Я» даны тем способом, который характерен для единого трансцендирующего опыта. (Gusserl', 1998, 222)
\end{abstract}

Таким образом, оказывается, что в лице аналогической апперцепции в моем распоряжении имеется трансцендирующий опыт, дающий мне знание о том, что независимо от моего Я реально существуют другие Я, трансцендентные моему. Аналогическая апперцепция как бы «прорывает» мою имма- 
нентность и «выводит» меня в трансцендентную действительность, которая представляет собой множество других Я, устроенных аналогично моему Я.

Гуссерль считает, что трансцендирующий опыт, полученный при помощи аналогической апперцепции, дает мне очевидное и не подлежащее сомнению знание. Если так, то угроза солипсизма устранена: мой трансцендентальный опыт со всей очевидностью говорит мне о том, что я отнюдь не одинок в своей имманентности, а нахожусь в компании других трансцендентальных еgo.

Применяя терминологию Лейбница, Гуссерль называет трансцендентные еgo «монадами». Он желает подчеркнуть, что монады эти - «без окон»: каждому трансцендентальному Я непосредственно даны лишь его собственные мысли, в мысли же других Я никакое трансцендентальное Я непосредственно проникнуть не может. Однако опосредствованно монады могут общаться друг с другом. Гуссерль говорит о том, что образуются «сообщества монад».

Входящие в сообщество монады способны понимать друг друга, могут сообщать друг другу, о чем они мыслят. Это осуществляется при помощи особого рода феноменов, именуемых знаками. В человеческом сообществе монад средством коммуникации является, как известно, членораздельная речь, язык. Ясно, что множеству знаков, сопоставляется множество феноменов, которые обозначены, и являются поэтому общими для всех монад, входящих в сообщество. О них члены сообщества могут беседовать, их они могут обсуждать. Все многообразие такого рода феноменов Гуссерль назвал «интерсубъективным миром». Понятно, что интерсубъективный мир не существует сам по себе, а является порождением общения монад друг с другом: если бы вдруг исчезли все до одной монады, то исчез бы и он.

Сообщество монад устроено так, что одна из них является центральной, изначальной, «примордиальной». Это моя монада, мое Я. Оно дано мне непосредственно, как бы «изнутри». Другие трансцендентальные Я даны только «снаружи»: непосредственно я могу воспринимать лишь феномены их живых тел; то, о чем они мыслят, я способен узнавать лишь опосредствованно. При этом все составляющие сообщество монады равноценны и равноправны в том смысле, что для каждой из них ее Я является центральным, изначальным и воспринимаемым «изнутри», в то время как все прочие Я для нее периферийны и воспринимаются только «снаружи». 
Казалось бы, дело обстоит, как нельзя лучше. Однако давайте более внимательно присмотримся к тому, что представляет собой аппрезентация, являющаяся аналогической апперцепцией. Прав ли Гуссерль? Способна ли она дать очевидное и несомненное знание о том, что за каждой аналогичной моей психофизической структурой «стоит» трансцендентное моему трансцендентальное Я? Обладает ли это свидетельство аналогической апперцепции той же степенью достоверности, что и первоначальная декартова истина: cogito ergo sum?

Увы, если подойти к делу непредвзято и во всем строго следовать Первому правилу Декарта, то, при всем уважении к Гуссерлю, придется дать на эти наши вопросы отрицательные ответы. К сожалению, аналогическая апперцепция способна так же «хромать», как и обычное умозаключение по аналогии. Ведь ее свидетельству о том, что за всяким феноменом другой психофизической структуры «стоит» другое трансцендентальное Я, трансцендентное моему, нетрудно противопоставить равное.

В самом деле, почему за наблюдаемыми мною психофизическими структурами обязательно должно стоять нечто трансцендентное? Почему все они не могут быть просто особого рода феноменами моего имманентного опыта, за которыми ничего не «стоит»? Почему они не могут быть такими же фантомами, такими же порождениями моего сознания, каковы те персонажи, с которыми я общаюсь во сне? Или вы скажете, что и за персонами из сновидений тоже «стоят» трансцендентальные еgo? Но такое утверждение весьма далеко отстояло бы от всякой очевидности и несомненности.

Как мы видели выше, Гуссерль в «Картезианских размышлениях» настаивает на том, что аналогическая апперцепция дает «трансцендирующий опыт». Но может ли опыт быть трансцендирующим? Не имеем ли мы тут дела с неким квазионтологическим доказательством? Вспомним, как строил свое онтологическое доказательство Декарт. Он обнаружил в своем сознании мысль о всесовершенном Существе, и отсюда сразу последовало, что Бог существует в реальной действительности независимо от сознания Декарта. А тут Гуссерль обнаруживает в сознании собственного трансцендентального Я феномены других психофизических структур, и отсюда при содействии аналогической апперцепции сразу следует, что в реальной действительности независимо от сознания Гуссерля существуют «стоящие» за ними другие трансцендентальные Я. Разница лишь в том, что у Декарта имеет место онтологическое дока- 
зательство бытия Божьего, а у Гуссерля - «квазионтологическое доказательство бытия человеческого».

Нет, мы никак не сможем согласиться с тем, что Гуссерлю удалось обнаружить некий «трансцендирующий» опыт, если не захотим хотя бы на йоту отступить от декартова Первого правила. Значит, не обладая «трансцендирующей силой», гуссерлева аналогизирующая апперцепция не способна «прорвать» мою имманентность и «вывести» меня за ее пределы. И значит, Гуссерль был не прав, пытаясь опереться на нее в «Картезианских размышлениях», а был прав, когда в «Идеях к чистой феноменологии и феноменологической философии» говорил, что все имманентное несомненно, а все трансцендентное сомнительно.

Но тогда трансцендентное существование других трансцендентальных Я оказывается лишь гипотетическим, равно как и существование интерсубъективного мира. В результате, гуссерлево учение о реальном существовании сообщества монад и интерсубъективного мира приобретает чисто догматический характер. Если со всей строгостью соблюдать Первое правило Декарта, то и сообщество монад, и интерсубъективный мир следует заключить в те же самые скобки, в которые Гуссерль уже поместил Бога и универсум трансцендентных вещей.

Таким образом, приходится констатировать, что Гуссерлю не удалось предотвратить угрозу трансцендентального солипсизма.

Жан-Поль Сартр тоже считал гуссерлевскую попытку победить солипсизм неудачной. При этом борьбу с солипсизмом он полагал необходимой и в своей книге «Бытие и ничто. Опыт феноменологической онтологии» предложил свой вариант решения этого вопроса. Сартру показалось, что несомненное свидетельство трансцендентного существования других Я находится в области эмоций. По его мнению, таких эмоций, как страх и стыд, у меня не могло бы быть, если бы не существовало трансцендентных других Я, каковые их мне внушают. Но такой поворот дела, к сожалению, не помогает, так как бывают ведь чисто фантомные страх и стыд. Поэтому одно только наличие в моем имманентном опыте подобного рода эмоций не может быть не подлежащим сомнению свидетельством того, что реально существуют трансцендентные другие ego. Избавиться от солипсизма не удается и при таком подходе к делу.

В общем, получается так, что Первое правило Декарта, требующее «никогда не принимать за истинное ничего, что я не признал бы таковым 
с очевидностью» и «включать в свои суждения только то, что никаким образом не сможет дать повод к сомнению», небезопасно: оно прямой дорогой ведет к трансцендентальному солипсизму. Если его принять и неуклонно соблюдать, то не оказывается ничего очевидного и не дающего повода к сомнению, кроме одной единственной истины: cogito ergo sum.

Однако если мы откажемся от соблюдения данного правила, то попадем в окружение множества равновероятных догматических учений, конкурирующих друг с другом, и выбирать между ними будет предоставлено нашему усмотрению. И тогда критерий истины перестанет быть самим собой, переместившись в область суждений вкуса. Или же нам придется возвратиться

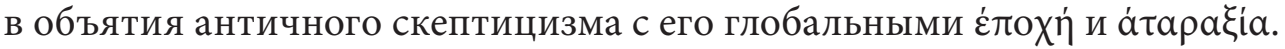

Давайте все-таки не будем отступать от Первого правила великого французского мыслителя, и вот почему. Гуссерль и Сартр боялись трансцендентального солипсизма, но, на самом деле, нечего его бояться: ведь он всего лишь трансцендентальный. Он не утверждает, что другие Я вообще не существуют: он говорит лишь о том, что их действительное существование не столь очевидно, сколь очевидно мое. Вот и все. При этом и в рамках трансцендентального солипсизма все члены сообщества монад находятся в одинаковом положении по отношению друг к другу: если для меня мое действительное существование несомненно, а Ваше - нет, то для Вас, если Вы действительно существуете, Ваше существование несомненно и очевидно, а мое - нет. И важно иметь в виду, что признание неизбежности трансцендентального солипсизма имеет лишь чисто теоретическое, чисто философское значение. Для житейской же практики совершенно безразлично, считаю я трансцендентное существование других трансцендентальных ego абсолютно достоверным или оно стоит у меня под вопросом. Для нее важно, что они существуют в виде феноменов изначального, примордиального мира моего ego cogito, что я могу с ними иметь общение, что я, таким образом, являюсь полноправным членом определенного сообщества монад, что я имею возможность осуществлять практические действия в пределах интерсубъективного мира того сообщества, в котором состою.

7.

Итак, со всей очевидностью передо мной предстоит мир моих когитатумов, мир моих интенциональных объектов, мир феноменов. Этот мир имеет 
чисто имманентный характер. Это мой изначальный, примордиальный мир. В нем выделяется такой феномен, как мое «живое тело», моя психофизическая структура. Наличествуют в нем и другие психофизические структуры. Я не знаю, имеют ли другие психофизические структуры трансцендентную «подоплеку»; очевидно лишь то, что как мои когитатумы, как мои феномены, они существуют, причем так, что моя психофизическая структура имеет возможность общаться, по крайней мере, с некоторыми из них, образуя вместе с такими психофизическими структурами некое сообщество, которое можно обозначить гуссерлевским термином: «сообщество монад». Гуссерль, правда, полагал, что другие психофизические структуры имеют-таки трансцендентную «подоплеку», однако даже если они ее лишены, то способность психофизических структур к общению имеет место со всей несомненностью, и в этом смысле говорить о сообществе монад позволительно.

Важно то, что такое сообщество монад центрировано: моя монада является центральной, а все остальные как бы «окружают» ее. При этом все мы находимся в одном, общем для всех, мире, в «интерсубъективном» мире, если позволительно воспользоваться еще раз терминологией Гуссерля.

Интерсубъективный мир - это прежде всего мир людей, мир монад, общающихся между собой при помощи членораздельной речи. Как человеку, мне присущи все черты, характерные для людей. Мое живое тело - это человеческое живое тело, я живу в человеческой семье, в человеческом обществе. Как и у всех, у меня есть свои обязанности, свои заботы, свои намерения, свои убеждения. В отношении своих чисто человеческих атрибутов, моя монада, в общих чертах, аналогична всем другим монадам, являющимися людьми.

Однако человеком я являюсь только в мире моих феноменов, моих когитатумов. Кроме того, что я человек, я ведь еще и трансцендентальное ego. Кроме слоя когитатумов, моя «имманенция» содержит еще и поток когитаций, дающих мне когитатумы. Она содержит также «субъектный полюс», из которого «исходят» все когитации, и о котором писал Гуссерль в «Картезианских размышлениях».

Да и как феномен, я не вполне аналогичен феноменам других людей. Так, например, мое живое тело выглядит в мире феноменов не совсем так, как выглядят живые тела других людей. Если тела других людей я могу непосредственно видеть со всех сторон: и спереди, и сзади, и сверху, и снизу, то с созерцанием моего собственного тела дело обстоит не так. Непосредственно 
я могу созерцать только свои грудь, живот, руки, ноги - все то, что находится спереди, но я не могу непосредственно видеть ни своего лица, ни головы, ни спины. Воспринимать их я способен лишь косвенно, опосредствованно, с теми или иными искажениями: в зеркале, на фотографии, на рисунке и т. п. Далее: мое тело постоянно находится здесь, при мне, никуда и никогда не исчезая. Тела же других людей пребывают не здесь, а там; они постоянно перемещаются, приближаются и удаляются, появляются и исчезают. Можно найти и другие черты, отличающие мою психофизическую структуру от психофизических структур других людей.

И наконец: в известном смысле я являюсь «хозяином» мира феноменов. Ведь это мой мир, мир моих феноменов. Что касается других людей, то они далеки от того, чтобы «хозяйничать» в нем: они суть всего лишь составные части этого мира.

Возникает вопрос: почему именно моя монада является центральной, почему именно мое Я стоит в центре мира и является его «собственником»? Ведь я ничем не лучше других людей, а по многим параметрам и гораздо хуже многих из них. Этот вопрос не имеет ответа. Поэтому то обстоятельство, что именно мое Я, со всеми его существенными и несущественными особенностями, стоит в центре мира и «заведует» им, следует считать одной из фундаментальных характеристик sum cogitans. Ее можно назвать контингентностью sum cogitans (от латинского глагола contingo - выпадать на долю, случаться, приключаться).

Другой фундаментальной характеристикой sum cogitans является его прерьвистость.

Мое существование в качестве Я мыслящего прерывчато. Оно имеет перерывы в своем течении. Что представляют собой эти перерывы? Они суть нечто обыденное и хорошо знакомое. Это, например, сон, или обморок, или потеря сознания от удара по голове, или кома, или наркоз, или что-нибудь еще в том же роде.

Слово «перерыв» подразумевает два момента: исчезновение и возникновение. Когда я засыпаю или впадаю в кому, я как sum cogitans исчезаю: ведь во сне или в обмороке я не мыслю и, следовательно, не существую. (Вопрос о сновидениях и тому подобном мы оставим в стороне, ориентируясь здесь исключительно на бодрствующее сознание.) Когда же я просыпаюсь или выхожу из комы, то как sum cogitans я возникаю: я снова мыслю и, следовательно, существую. 
Понятно, что sum cogitans прерывисто целиком и полностью, вместе со своими когитациями, когитатумами и «субъектным полюсом». И теперь уже совсем ясно, в каком смысле я являюсь «хозяином» мира феноменов: его существование целиком и полностью зависит от моего существования. Когда я засыпаю или впадаю в кому, тогда мир феноменов прекращает свое существование, а когда я просыпаюсь или выхожу из комы, тогда он его возобновляет. Ничего подобного не происходит, когда засыпают и пробуждаются другие, когда они впадают в кому и выходят из нее: мир феноменов продолжает при этом непрерывно существовать, как ни в чем не бывало.

Теперь вспомним, что находимся в пределах трансцендентального солипсизма и что, следовательно, sum cogitans - это единственное абсолютно достоверное бытие. И оно прерывчато: бытие сменяется небытием, а небытие бытием. Одно постоянно следует за другим.

Но ведь имеется незыблемый закон Парменида: «Есть бытие, а небытия нет». При этом Парменид задолго до нас знал, что «одно и то же мысль и предмет мысли» в отношении их бытия. Парменид знал, что все, о чем мы способны мыслить и говорить, существует. Поэтому о небытии как таковым ничего нельзя ни сказать, ни помыслить, так как его нет. Говоря: «небытие», я сразу делаю то, о чем говорю, бытием, так как все, о чем я говорю, существует. О небытии как таковом, об абсолютном небытии мы не способны ничего сказать прямо: мы говорим о нем только косвенно, обиняком, намеками, кружим вокруг да около.

Однако если о едином абсолютном небытии, которого нет, мы говорим лишь косвенно, то об относительном многообразном небытии, которое «проникло» в единое бытие и сделало его множественным, мы говорим прямо. Платон в диалоге «Софист» присвоил такому небытию наименование «иное». С такого рода небытием мы сталкиваемся, когда говорим о небытии кем-то или чем-то, о неимении чего-то, об отсутствии там-то, о нехватке того-то и т.п.

Но что представляет собой небытие вносящее перерывы в плавное течение sum cogitans? Это, конечно, не абсолютное небытие, но и относительным его не назовешь: ведь оно имеет не частичный, а глобальный характер. В самом деле, иным я являюсь всегда по отношению к чему-то или кому-то, оставаясь при этом самотождественным бытием. А тут я, как sum cogitans, как бодрствующее сознание, время от времени отсутствую целиком и полностью.

Такое небытие позволительно назвать ограниченным, ибо оно как бы «с двух сторон ограничено» бытием. Когда я бодрствую, его просто нет, 
в полном соответствии с формулой Парменида. Когда я, допустим, засыпаю, но еще не заснул, тогда его еще нет. А когда я проснулся, тогда его уже нет. При этом для бодрствующего сознания в промежутке между отходом ко сну и пробуждением нет ничего. Непосредственно оно этот промежуток воспринять не способно. О том, что был промежуток небытия в моем бытии, мне становится известно лишь благодаря косвенным признакам. Промежуток этот всегда либо был, либо будет, но никогда не есть.

Теперь вопрос: что если течение sum cogitans, однажды прервавшись, никогда больше не возобновится? Ниоткуда не следует необходимость возникновения такой ситуации, но возможность ее появления не исключена. Если бы означенная возможность осуществилась, то ограниченное небытие потеряло бы очередную свою границу и сделалось бы впредь неограниченным.

Позволительно спросить: а не тождественно было бы возникшее таким образом неограниченное небытие абсолютному небытию Парменида, о котором прямо нельзя ничего сказать и ничего помыслить?

И не это ли неограниченное небытие имел в виду Хайдеггер, когда спрашивал: «Почему бытие, а не ничто?» Ведь такое небытие гораздо фундаментальнее бытия. Почему, в самом деле, имеется бытие, да еще в такой странной и несерьезной форме - в виде ничем не примечательного меня? Разве соразмерно подобное бытие с безграничным парменидовым небытием, которое, возможно, маячит где-то у него впереди, готовясь его поглотить?

\section{REFERENCES}

Dekart, R. (1989a). Rassuzhdenie o metode, chtoby verno napravlyat' svoi razum i otyskivat' istinu $\mathrm{v}$ naukakh [Discourse on the Method of Rightly Conducting One's Reason and of Seeking Truth in the Sciences]. In R. Deskartes, Sochineniya v dvukh tomakh [Works in Two Volumes. Vol. 1] (250-296). Moscow: Mysl'. (in Russian).

Dekart, R. (1989b). Pervonachala filosofii [Principles of Philosophy]. In R. Deskartes, Sochineniya $v$ dvukh tomakh [Works in Two Volumes. Vol. 1] (297-422). Moscow: Mysl'. (in Russian).

Dekart, R. (1994). Razmyshleniya o pervoi filosopfii, v koikh dokazyvaetsya sushchestvovanie Boga i razlichie mezhdu chelovecheskoi dushoi i telom [Meditations on First Philosophy in which the Existence of God and the Immortality of the Soul are Demonstrated]. In R. Deskartes, Sochineniya $v$ dvukh tomakh [Works in Two Volumes. Vol. 2] (3-73). Moscow: Mysl'. (in Russian).

Gusserl', E. (1909) Logicheskie issledovaniya. Chast' pervaya. Prolegomeny k chistoi logike [Logical Investigations. Part 1. Prolegomena to Pure Logic]. St. Petersburg: "Obrazovanie". (in Russian).

Gusserl', E. (1998) Kartezianskie razmyshleniya [Cartesian Meditations]. St. Petersburg: Science. (in Russian). 
Gusserl', E. (2009) Idei k chistoi fenomenologii i fenomenologicheskoi filosofii [Ideas Pertaining to a Pure Phenomenology and to a Phenomenological Philosophy]. Moscow: Akademical Project. (in Russian).

Sekst Empirik. (1976). Tri knigi pirronovykh polozhenii [Outlines of Pyrrhonism]. In Sexstus Empiricus, Sochineniya $v$ dvukh tomakh [Works in Two Volumes. Vol. 2] (207-380). Moscow: Mysl'. (in Russian). 